\title{
Soft Tissue Sarcoma pT1 TNM Finding v7
}

National Cancer Institute

\section{Source}

National Cancer Institute. Soft Tissue Sarcoma pT1 TNM Finding v7. NCI Thesaurus. Code C88454.

Soft tissue sarcoma with tumor measuring $5 \mathrm{~cm}$ or less in greatest dimension. (from AJCC 7th Ed.) 